\title{
On the taxonomic status of some South American Eucyclops (Copepoda: Cyclopidae: Eucyclopinae)
}

\author{
Nancy Fabiola Mercado-Salas ${ }^{1,2, *}$ and Eduardo Suárez-Morales ${ }^{3}$
}

1 German Centre for Marine Biodiversity Research (DZMB), Senckenberg am Meer Wilhelmshaven, Südstrand 44, 26382 Wilhelmshaven, Germany.

2 Centrum für Naturkunde - CeNak/Center of Natural History Hamburg, Universität Hamburg - Zoological

Museum, Martin-Luther-King-Platz 3, 20146 Hamburg, Germany

${ }^{3}$ El Colegio de la Frontera Sur (ECOSUR), Unidad Chetumal. Av. Centenario Km. 5.5, Chetumal, Quintana

Roo, 77014. Mexico.

* Corresponding author: nancy.mercado.salas@uni-hamburg.de

Received: $12 / 11 / 18 \quad$ Accepted: 03/06/19

\begin{abstract}
On the taxonomic status of some South American Eucyclops (Copepoda: Cyclopoida: Eucyclopinae)

Among eucyclopinids freshwater copepods, the genus Eucyclops contains several species or species groups whose taxonomic status has not been properly determined and is in need of revision or redescription. Traditionally used meristic characters have recently been deemed insufficient for resolving these problems, particularly in respect of the South American taxa. New, upgraded descriptive standards and molecular tools have contributed greatly to the clarification of some of these cases in both Europe and the Americas. Based on examination of type specimens and museums' collections, and following currently accepted taxonomic standards, we were able to clarify the status of some problematic South American species of Eucyclops. We provide herein a redescription of three South American species (i.e., E. pseudoensifer, E. breviramatus, and E. subciliatus), each with a history of poorly understood affinities with other American Eucyclops. The nominal Eucyclops neumani, described by Pesta (1927) and originally described from Argentina, was known to contain two subspecies: E. neumani neumani, recorded in Argentina, Paraguay, and Brazil, and E. neumani titicacae (Kiefer, 1957), known only from Peru and Colombia. Based on our analysis, we conclude that E. titicacae is not a subspecies of E. neumani, but a separate species, distinguishable from its closest congeners. We also provide evidence showing that neither E. pseudoensifer nor E. breviramatus are members of the E. serrulatus species group.
\end{abstract}

Key words: freshwater crustaceans, taxonomy, morphology, zooplankton

\section{RESUMEN}

\section{Revisión del estatus taxonómico de algunos Eucyclops (Copepoda, Cyclopoida, Eucyclopinae) de Sudamérica}

Entre los copépodos euciclópinos, el género Eucyclops contiene varias especies o grupos de especies cuya situación taxonómica no se ha resuelto adecuadamente y requieren revisión o redescripción. Los caracteres meristicos tradicionalmente utilizados han sido considerados como insuficientes para desentrañar estos problemas, particularmente entre especies sudamericanas. Los estándares descriptivos actuales y las herramientas moleculares han contribuido mucho a aclarar algunos de estos casos tanto en Europa como en América. Con base en el estudio de especímenes tipo, colecciones de museos y siguiendo estándares taxonómicos mejorados y actualizados, hemos podido aclarar el estado de algunas especies problemáticas de Eucyclops conocidas en Sudamérica. Presentamos redescripciones de tres especies sudamericanas (i.e., E. pseudoensifer, E. breviramatus, E. subciliatus), cada una de ellas con una historia de afinidades poco claras respecto a otras especies americanas de Eucyclops. La especie nominal Eucyclops neumani (Pesta, 1927), originalmente descrita de Argentina, incluye dos subespecies, E. neumani neumani, encontrada en Argentina, Paraguay y Brasil, y E. neumani titicacae Kiefer, 1957, conocida solo en Perú y Colombia. Basándonos en nuestro análisis, llegamos a la conclusión de que E. titicacae no debe ser considerada una subespecie de E. neumani, sino una especie separada, distinguible de sus congéneres más cerca- 
nos. Derivado de la redescripción de estas tres especies sudamericanas, logramos aclarar su situación taxonómica y su afinidad con otros Eucyclops americanos. También proporcionamos evidencias que muestran que tanto E. pseudoensifer como E. breviramatus no deben ser considerados como parte del grupo de especies de E. serrulatus.

Palabras clave: taxonomía, copépodos continentales, Eucyclops

\section{INTRODUCTION}

The current knowledge of the genus Eucyclops in the Americas is based on more than 800 records obtained from the taxonomic work conducted over 100 years of biological sampling across the entire continent. Up to 36 nominal species of this genus have been recorded in the Americas, with most records coming from the United States, Mexico, Argentina, and Brazil (Reid, 1985; Mercado-Salas et al., 2012; Mercado-Salas et al., 2016). In South America, there are more than 150 extant records that correspond to 20 nominal species, Nine of these species are considered South American endemics (i.e., E. silvestri [Brian, 1927], E. neumani [Pesta, 1927], E. neotropicus [Kiefer, 1936], E. titicacae [Kiefer, 1957], E. alticola [Kiefer, 1957], E. demacedoi [Lindberg, 1957], E. siolii [Herbst, 1962], E. subciliatus [Dussart, 1984a], and E. chilensis Suárez-Morales \& Walsh, 2009, with another 8 species reported in Central and North America (i.e., Eucyclops elegans [Herrick, 1884], E. delachauxi [Kiefer, 1925], E. prionophorus [Kiefer, 1931], E. bondi [Kiefer, 1934], E. ensifer [Kiefer, 1936], E. leptacanthus [Kiefer, 1956], E. breviramatus [Löffler, 1963], and E. pseudoensifer [Dussart, 1984]). A few nominal species of Eucyclops are known as cosmopolitan forms, presumably representing species-complexes: E. serrulatus (Fischer, 1851), $E$. agilis (synonym to $E$. serrulatus) and $E$. speratus (Lilljeborg, 1901) (see Kiefer, 1936; Lindberg, 1954; Dussart, 1984, 1984a; Reid, 1985; Dussart \& Frutos, 1986; Defaye \& Dussart, 1988; Santos \& Andrade, 1997; Gaviria \& Aranguren, 2007; Silva, 2008; De los Ríos et al., 2010; Mercado-Salas et al., 2012).

This genus is one of the most taxonomically challenging groups among the Cyclopidae because it contains several problematic taxa and species complexes with high intraspecific variability, a problem shared with other cyclopoid copepod genera like Acanthocyclops (Miracle et al., 2013). Until recently, only a few species of Eucyclops have complete, upgraded descriptions. In the last 10 years, several valuable taxonomic advances have been published, especially in the Americas, to clarify the taxonomic status of these taxa. Some of these species are now defined more accurately because of the use of new morphological characters and the analysis of their geographic distributional patterns (Alekseev et al., 2006; Defaye \& Alekseev, 2011; Mercado-Salas et al., 2012; Mercado-Salas \& Suárez-Morales, 2014a, b; Mercado-Salas et al., 2016). The key requirements for clarifying these closely related species of the American Eucyclops include: (1) the revision of the type specimens, (2) redescription of some species following upgraded standards, and (3) examination of additional material held in different zoological collections, especially at the Muséum National d'Histoire Naturelle (France), the Staatliches Museum für Naturkunde Karlsruhe (Germany), the National Museum of Natural History, Smithsonian Institution (USA), and the Natuurhistorisch Museum Wien (Austria). In previous works, we discussed the taxonomic position of some Eucyclops described by F. Kiefer (Karlsruhe) (see Mercado-Salas \& Suárez-Morales, 2014a) and compared both the type specimens and the original descriptions and illustrations with the Mexican material that was labeled with these names. In this contribution we analyze and/or redescribe a group of South American species of Eucyclops including type specimens of E. neumani, E. subciliatus, and E. pseudoensifer deposited in the B.H. Dussart's Collection in Paris, and E. chilensis and E. breviramatus from the Heinz Löffler's Collection in Wien. These species are taxonomically analyzed and compared with additional material and records found at F. Kiefer's Collection in Karlsruhe. We present an upgraded redescription of Eucyclops pseudoensifer, E. 


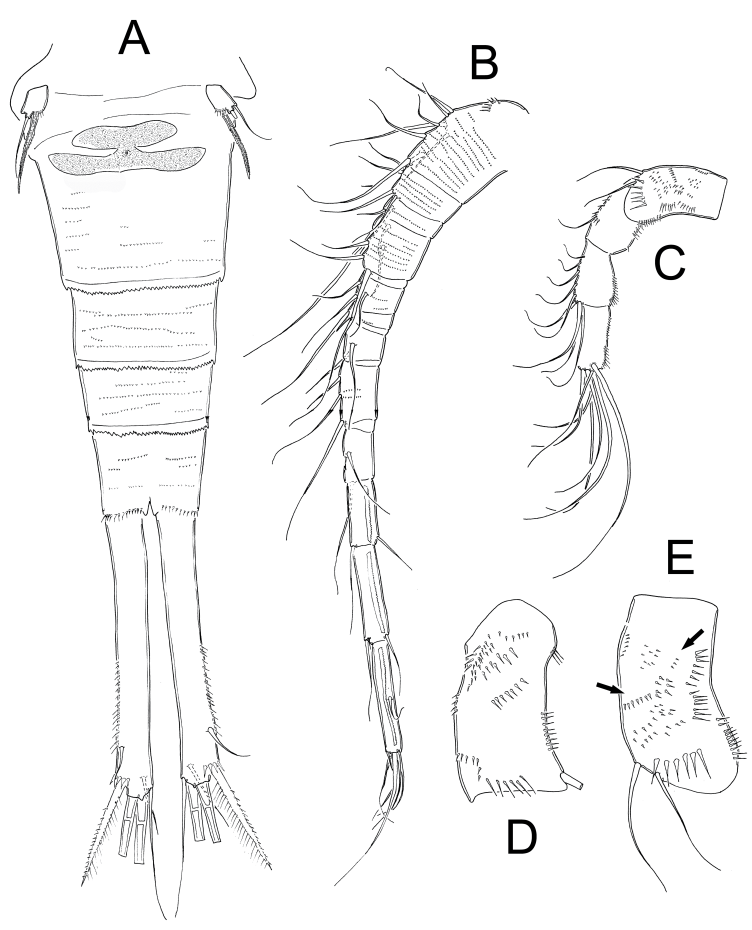

Figure 1. Eucyclops neumani s. str. (Pesta, 1927), adult female (MNHN-IU-2010-6807) from Argentina: A. urosome, ventral view; B. antennule; C. antenna; D. antennary basipodite, frontal view; E. antennary basipodite, caudal view. Eucyclops neumani s. str. (Pesta, 1927), hembra adulta (MNHN-IU-2010-6807) de Argentina. A. urosoma, vista ventral; $B$. anténula; $C$. antena; $D$. basipodito de la antena, vista frontal; E. basipodito de la antena, vista caudal.

neumani, E. subciliatus, and E. breviramatus. Due to editorial space constraints, the redescription of the taxonomically problematic E. chilensis will be provided in a further contribution.

\section{MATERIALS AND METHODS}

The redescription of both E. pseudoensifer and $E$. subciliatus was based on the examination of the type specimens from B. Dussart's collection deposited at the Muséum National d'Histoire Naturelle in Paris (France) (MNHN). Our redescription of $E$. neumani s. str. was based on the revision of samples from Argentina deposited in B.H. Dussart's collection; moreover, we compared our observations with F. Kiefer's accessory collection of drawings (Staatliches Museum für Naturkunde, Karlsruhe) of different populations of E. neumani.
The present redescription of E. breviramatus was based on the type specimens from H. Löffler's collection (Naturhistorisches Museum, Wien). Drawings were prepared at $1000 \times$ magnification with a Leitz Medilux compound microscope equipped with a drawing tube. Mapping and nomenclature of spinule and setule rows on the antennary basis, the coxopodite, and the intercoxal plate of P4 followed Alekseev et al. (2006) and Alekseev \& Defaye's (2011) criteria. Abbreviations used in the descriptive section are: P1-P4 $=$ first to fourth legs, $\operatorname{Exp}=$ exopod, Enp = endopod, $\mathrm{s}=$ seta/ae, ae $=$ aesthetasc, $\mathrm{sp}=$ spine, $\mathrm{Bsp}=$ basipod, and $\mathrm{CR}=$ caudal ramus. The nomenclature used to describe the antennule and antennary armatures followed Alekseev et al. (2006), Alekseev \& Defaye (2011), and Mercado-Salas et al. (2016). Caudal seta were labeled as follows: II - anterolateral (lateral) caudal seta, III-posterolateral (outermost) caudal seta, IVouter terminal (terminal median external) caudal seta, V-inner terminal (terminal median internal) caudal seta, VI-terminal accessory (innermost) caudal seta, and VII-dorsal seta. The terms furca and telson were used following Schminke (1976). The museum specimens examined were either mounted on sealed slides or originally fixed and preserved in formalin, thus preventing the use of molecular analyses.

\section{RESULTS}

Order Cyclopoida (Rafinesque, 1815)

Family Cyclopidae (Rafinesque, 1815)

Subfamily Eucyclopinae (Kiefer, 1927)

Genus Eucyclops (Claus, 1893)

Eucyclops neumani s. str. (Pesta, 1927).

(Figures 1-4)

Material examined: adult female from Chaco, Argentina (MNHN-IU-2010-6807), St. R32, Arroyo del Tres; date of collection: September 19, 1984; collector S.M. Frutos; B. H. Dussart Collection, Muséum National d'Histoire Naturelle in Paris, France.

Female: average length excluding caudal setae = $1.34 \mathrm{~mm}$. Urosome five-segmented (Fig. 1A), elongated; all urosomites ornamented with rows of 


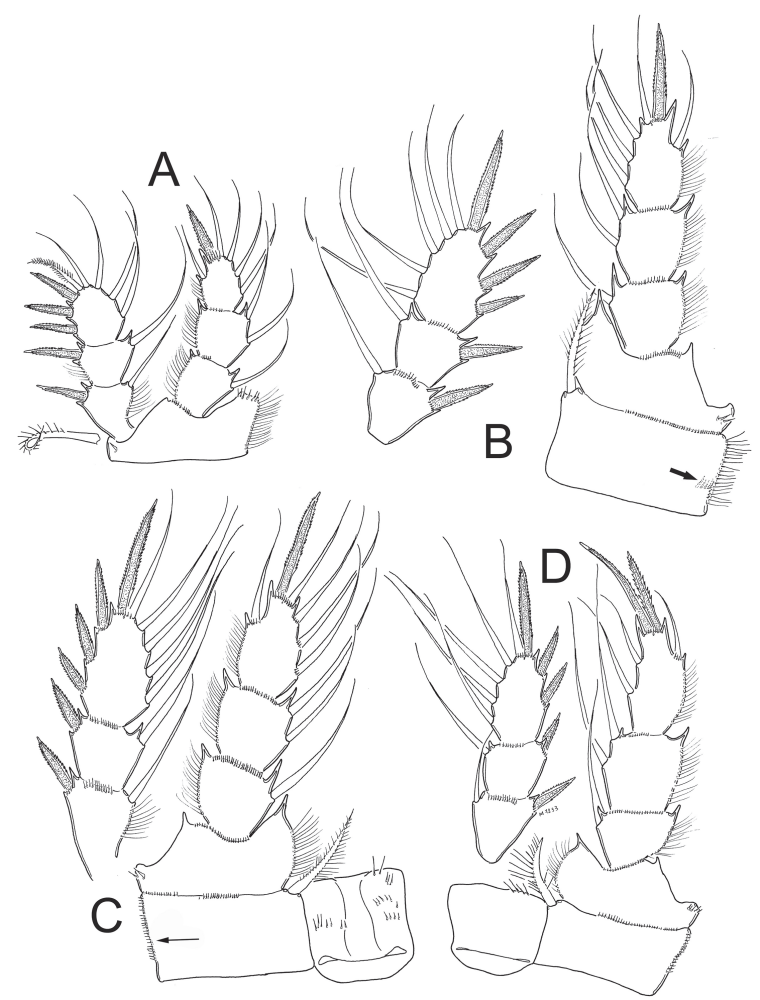

Figure 2. Eucyclops neumani s. str. (Pesta, 1927), adult female (MNHN-IU-2010-6807) from Argentina: A. leg 1; B. leg 2, exopodite separated for illustration; C. leg 3, idem; D. leg 4, idem. Eucyclops neumani s. str. (Pesta, 1927), hembra adulta (MNHN-IU-2010-6807) de Argentina. A. pata 1; B. pata 2, el exopodito se ilustra por separado; C. pata 3, el exopodito se ilustra por separado; D. pata 4, el exopodito se ilustra por separado.

cuticular pits. Posterior margin of telson with single row of spinules. Genital double-somite symmetrical. Seminal receptacle similar to the serrulatus-group, with narrow lateral arms on posterior margin. Genital somite 1.2 times longer than wide. Anal somite with cluster of small hair-like setules at each side of anal opening (see Fig. 33 in Dussart \& Frutos, 1986), anal operculum rounded, with medial gap (see Fig. 33 in Dussart \& Frutos, 1986; arrowed in Fig. 3B). Length/width ratio of $\mathrm{CR}=8.4$; inner margin of $\mathrm{CR}$ smooth. Serra covering 10-30\% of outer margin, with 6-15 spinules (Pesta, 1927; Dussart \& Frutos, 1986; pers. obs. NM-S) (Figs. 1A, 3C-E). Dorsal seta (VII) short; about 0.25 times the length of CR and 0.60 times as long as outermost caudal seta (III). Length ratio of innermost caudal seta (VI)/ outermost caudal seta (III) $=1.15$. Lateral caudal seta (II) inserted at $80-88 \%$ of CR. All terminal caudal setae plumose.

Antennule (A1) (Fig. 1B): 12-segmented. Armature per segment as follows: $(\mathrm{s}=$ seta, ae $=$ aesthetasc, $\mathrm{sp}=$ spine): 1(8s), 2(4s), 3(2s), 4(6s), $5(3 \mathrm{~s}), 6(1 \mathrm{~s}+1 \mathrm{sp}), 7(2 \mathrm{~s}), 8(3 \mathrm{~s}), 9(2 \mathrm{~s}+1 \mathrm{ae})$, $10(2 s), 11(3 s)$, and $12(7 s)$. Segments 1-8 furnished with rows of small pits (see Fig. 1B).

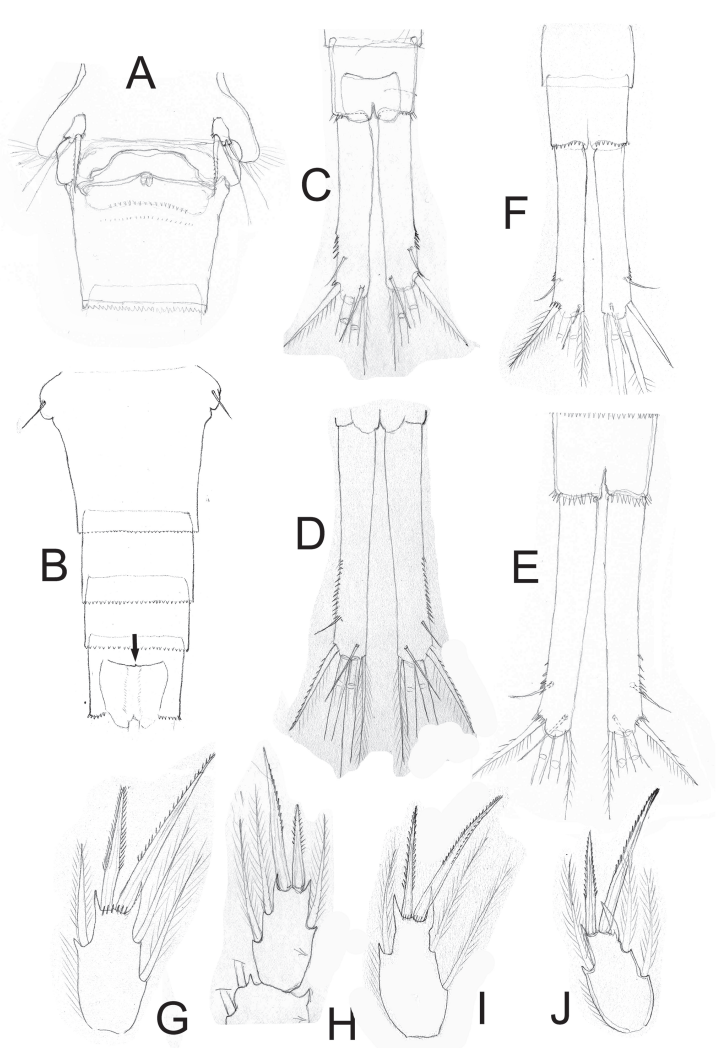

Figure 3. Eucyclops neumani s. str. (A-E, Pesta, 1927), Eucyclops titicacae (F-J, Kiefer, 1956): A. genital double somite (SMNK-11154); B. urosome, dorsal view (SNMK-02879); C. caudal rami (SNMK-11149); D. caudal rami (SNMK-02879); E. caudal rami (SNMK-11154); F. caudal rami (SNMK-05753); G. leg 4 (SNMK-03107); H. leg 4 (SNMK-11149); I. P4 (SNMK-02879); J. P4 (SNMK-02753). Eucyclops neumani s. str. (Pesta, 1927) A-E, G-I; Eucyclops titicacae Kiefer, 1956 F, J. A. doble somita genital (SMNK-11154); B. urosoma, vista dorsal (SNMK-02879); C. ramas caudales (SNMK-11149); D. ramas caudales (SNMK-02879); E. ramas caudales (SNMK-11154); F. ramas caudales (SNMK-05753); G. pata 4 (SNMK-03107); H. pata 4 (SNMK-11149); I. pata 4 (SNMK-02879); J. pata 4 (SNMK-02753). 
Antenna (A2) (Figs. 1C-E): basis (2s + Exp), plus three-segmented Enp (armature: 1s, 9s, 7s). Ornamentations of basis (sensu Alekseev and Defaye, 2011) as follows: on frontal surface, $\mathrm{N} 1(6), \mathrm{N} 2(6), \mathrm{N} 3(7), \mathrm{N} 4(20$ in group), N5(6), N6(3), and N17(8); and on caudal surface N7(18 in group), N8(6), N9+10(9), N11(7), N12(6), N13(7 in group), N14(9 in group), N15(3), and $\mathrm{N} 16(7)$ additional rows of spinules below N7 and another between N12 and N14 (both arrowed in Fig. 1E).

Mouthparts: not observable in slides.

P1-P4: Enp and Exp of all legs three-segmented. Armature formula as in Table 1.

P1 (Fig. 2A): intercoxal sclerite ornamentation not observable in slides. Basipodal spine reaching middle margin of Enp3 $=0.7$ times as long as Enp. Length/width ratio of Enp3 P4 $=1.3$; ratio of apical spine/length of Enp3 = 1.2.

P2 (Fig. 2B): intercoxal sclerite ornamentation not observable in slides. Coxa with row of hair-like setules along outer margin; one transversal row of spinules on middle margin, close to outer margin (caudal view) (arrowed in Fig. 2B), small spinules at insertion of Enp.

P3 (Fig. 2C): intercoxal sclerite with three rows of spinules on caudal surface: first row close to apical margin, bearing five spinules on each side; second row transverse, with tiny spinules along medial margin; third one a tramsverse a transversal row of small spinules located below the second row. Distal margin of intercoxal sclerite

Table 1. Setal formula of legs 1-4 in the type specimens of species of Eucyclops studied; spines in Roman numerals, setae in Arabic numerals; (-) represents structures not observed on the type material. Fórmula setal de las patas 1-4 en los especímenes tipo de las especies de Eucyclops que fueron estudiadas; (espinas en números romanos, setas en números arábigos). (-) representa estructuras no observadas en el material tipo.

\begin{tabular}{|c|c|c|c|c|c|}
\hline Species & & Coxa & Basis & $\operatorname{Exp}$ & Enp \\
\hline \multirow[t]{4}{*}{ E. neumani s. str. } & $\mathrm{P} 1$ & $0-1$ & $1-\mathrm{I}$ & I-1; I-1; III-5 & $0-1 ; 0-1 ; 1-\mathrm{I}-4$ \\
\hline & $\mathrm{P} 2$ & $0-1$ & $1-0$ & $\mathrm{I}-1 ; \mathrm{I}-1 ; \mathrm{IV}-5$ & $0-1: 0-2: 1-\mathrm{I}-4$ \\
\hline & P3 & $0-1$ & $1-0$ & $\mathrm{I}-1 ; \mathrm{I}-1 ; \mathrm{IV}-5$ & $0-1 ; 0-2 ; 1-\mathrm{I}-4$ \\
\hline & $\mathrm{P} 4$ & $0-1$ & $1-0$ & I-1; I-1; III-5 & $0-1 ; 0-2 ; 1-\mathrm{II}-2$ \\
\hline \multirow[t]{4}{*}{ E. subciliatus } & $\mathrm{P} 1$ & $0-1$ & $1-\mathrm{I}$ & $\mathrm{I}-1, \mathrm{I}-1, \mathrm{III}-5$ & $0-1,0-2,1-\mathrm{I}-4$ \\
\hline & $\mathrm{P} 2$ & $0-1$ & $1-0$ & $\mathrm{I}-1 ; \mathrm{I}-1 ; \mathrm{IV}-5$ & $0-1 ; 0-2 ; 1-\mathrm{I}-4$ \\
\hline & P3 & $0-1$ & $1-0$ & $\mathrm{I}-1, \mathrm{I}-1, \mathrm{IV}-5$ & $0-1,0-2,1-\mathrm{I}-4$ \\
\hline & $\mathrm{P} 4$ & $0-1$ & $1-0$ & $\mathrm{I}-1, \mathrm{I}-1, \mathrm{III}-5$ & $0-1,0-2,1-\mathrm{II}-2$ \\
\hline \multirow[t]{4}{*}{ E. pseudoensifer } & $\mathrm{P} 1$ & $0-1$ & $1-\mathrm{I}$ & I-1; I-1; III-3 & $0-1 ; 0-1 ; 1-\mathrm{I}-4$ \\
\hline & $\mathrm{P} 2$ & $0-1$ & $1-0$ & $\mathrm{I}-1 ; \mathrm{I}-1 ; \mathrm{IV}-5$ & $0-1: 0-2: 1-\mathrm{I}-4$ \\
\hline & P3 & $0-1$ & $1-0$ & $\mathrm{I}-1 ; \mathrm{I}-1 ; \mathrm{IV}-5$ & $-;-;-$ \\
\hline & P4 & $0-1$ & $1-0$ & I-1; I-1; III-5 & $0-1 ; 0-2 ; 1-\mathrm{II}-2$ \\
\hline
\end{tabular}




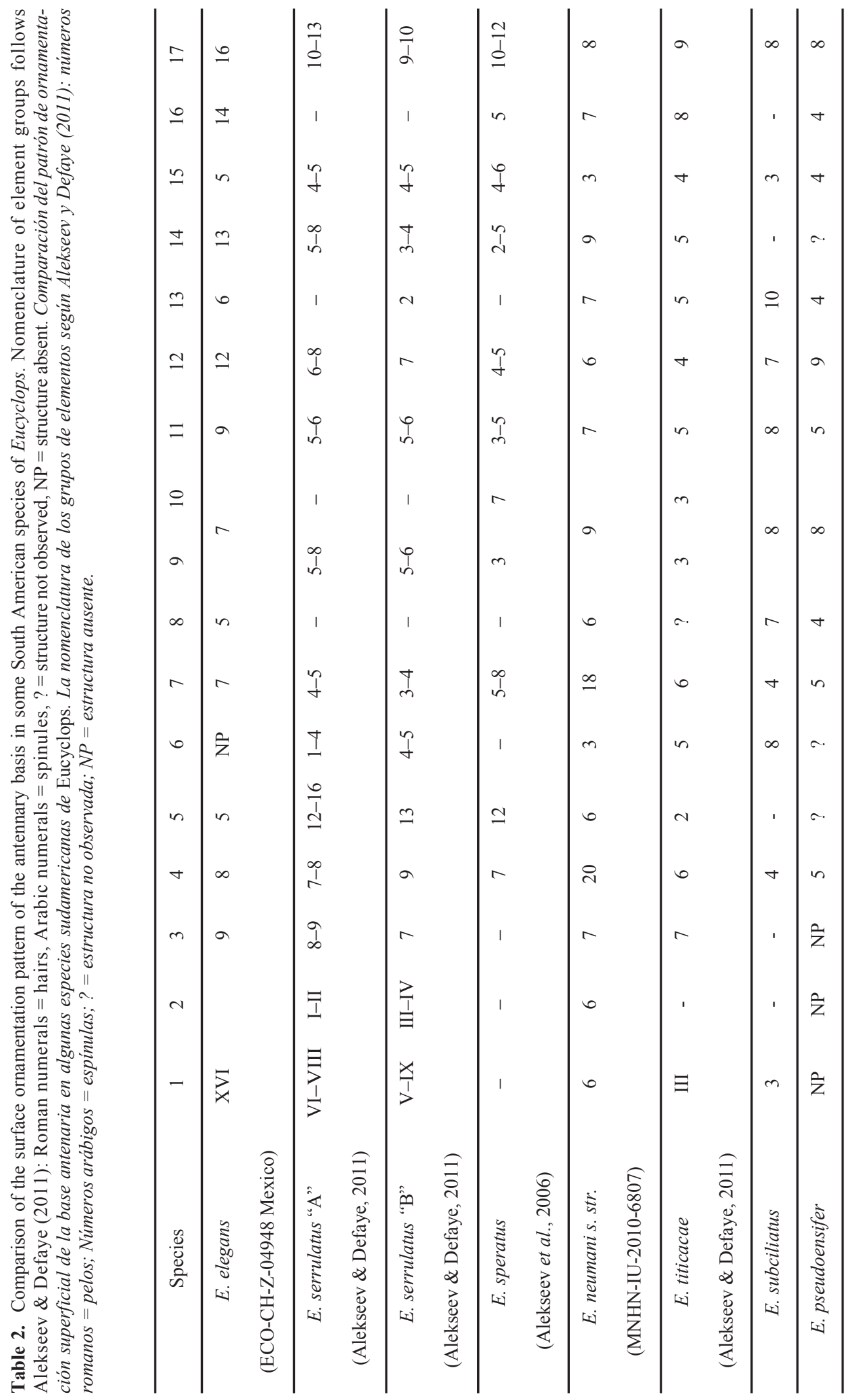


with two slightly rounded projections. Coxa with strong biserially setulated coxal seta and tiny spinules along outer margin (arrowed in Fig. 2C). Unmodified seta on Enp3 and Exp3. All spines in Exp with tiny spinules at insertion.

P4 (Fig. 2D): intercoxal sclerite only, with row I observable, represented by four or five spinules on each side and a small medial gap. Inner coxal spine with heteronomous ornamentation: basally, with long hair-like setules; distally, with short spine-like setules; outer edge with hair-like setules on the proximal surface. Length/width ratio of Enp3 $\mathrm{P} 4=2.2$; length ratio of inner/outer spines of Enp3 P4 $=1.3$; length ratio of inner spine of Enp3 P4/length Enp3 P4 = 1.1; length ratio of outer spine of Enp3 P4/length Enp3 P4 = 0.8. Lateral seta of Enp3 P4 inserted at $75 \%$ of the total length of the segment. No modified setae on Enp3 and Exp3. Spines of Exp with tiny spinules at the insertion.

P5 (Fig. 1A): free segment subrectangular, 1.4 times longer than wide; bearing one inner spine and two setae; medial seta as long as outer seta; inner spine slightly longer than setae (about 1.1 times longer); inner spine 2.4 times longer than segment.

Remarks: The strikingly elongate CR is among the main characters to distinguish Eucyclops neumani $\mathrm{s}$. str. from its congeners, but this feature is shared with other species like E. elegans, E. speratus, E. macruroides s. str. (Lilljeborg, 1901), E. roseus (Ishida, 1997), and E. pacificus (Ishida, 2000). Of these, only E. elegans is found in the Americas and can be easily distinguished from $E$. neumani s. str. because its serra covers more than $70 \%$ of the CR outer margin, whereas in $E$. neumani $\mathrm{s}$. str. this ornamentation covers only 30 $\%$ of the CR outer margin. Another character that clearly separates the two species is the shape and size of the P5 setal elements. In E. elegans the medial seta is always the longest and the outer one the shortest, the inner spine is long, strong, longer than the outer seta. A different pattern was found in E. neumani s. str. P5: the medial seta was as long as, or slightly longer than, the outer seta, and the outer seta is always as long as or slightly shorter than the inner spine; thus, in E. neumani s. str. the three elements of P5 are subequally long. The ornamentation of both the frontal and caudal surfaces of the antennary basis also differs between these two species. In E. elegans rows N1 and N2 bear long hairs and are not clearly separated, appearing as part of a single group; in $E$. neumani $\mathrm{s}$. str. those two rows are clearly separated from each other and formed by small spinules. Both species present additional rows of spinules compared with the general pattern described by Alekseev et al. (2006), Alekseev \& Defaye (2011), and Mercado-Salas et al. (2016). In E. neumani s. str. one extra row is found adjacent to group N7 and is probably part of group N22; another row was observed between groups N12 and N14, probably assignable to Mercado-Salas et al.'s (2016) group N20; in E. elegans only one extra row was found between groups N15 and N17 and is herein recognized as row N18.

During a visit to F. Kiefer's copepod collection (Staatliches Museum für Naturkunde, Karlsruhe), we examined his illustrations of the American Eucyclops. We found drawings of four populations of E. neumani s. str. and the original illustrations of E. titicacae. In Table 3, we provide a comparison of the main meristic characters resulting from the observation of this material. Also, we compared this data with the meristic values obtained from the examination of material from B. H. Dussart's collection and also with drawings by Pesta (1927) and Dussart \& Frutos (1986). In this way, we were able to obtain a reasonably complete overview of the morphological variability of this species in its known distributional range and compare it with E. neumani titicacae in order to determine if the subspecific status of the latter is supported. In Kiefer's collection we examined illustrations of $E$. neumani s. str. from Uruguay (SMNK-03107), Lago Rupanco, Chile (SMNK-11149), Recife, Brazil (SMNK-02879), Río Cruce, Chile (SMNK-11154), and of E. titicacae from Lake Titicaca, Peru (SMNK- 05752, SMNK-05753, SMNK-05754). As shown in Table 3 and in Figures 3 and 4, most meristic values in this analysis have reduced variation ranges; only a few characters showed sizable variations among populations: (1) the CR length/width ratio range (5.8-8.4), (2) the P5 free segment length/width ratio range (1.0-2.0), and most importantly, (3) 


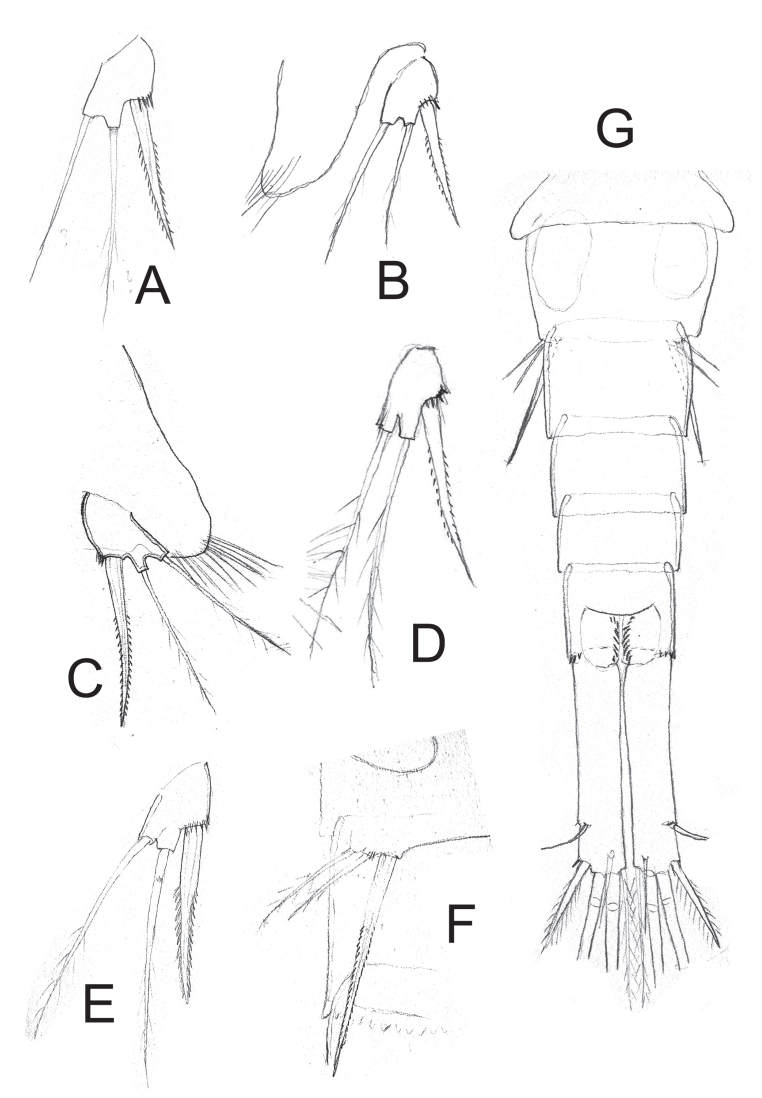

Figure 4. Eucyclops neumani s. str. (A-D, Pesta, 1927): Eucyclops titicacae (E-G, Kiefer, 1956): A. leg 5 (SNMK-03107), B. leg 5 (SNMK-11149); C. P5 (SNMK-02879); D. P5 (SNMK-11154); E. P5 (SNMK-05752); F. leg 6 (SNMK-05754); G. urosome, dorsal view (SNMK-05754). Eucyclops neumani s. str. (Pesta, 1927) A-D; Eucyclops titicacae Kiefer, 1956 E-G. A. pata 5 (SNMK-03107), B. pata 5 (SNMK-11149); C. pata 5 (SNMK-02879); D. pata 5 (SNMK-11154); E. pata 5 (SNMK-05752); F. pata 6 (SNMK-05754); G. Urosoma, vista dorsal (SNMK-05754).

the proportional length of the P5 medial seta/inner spine.

Based on these results, the latter character is arguably the main one to distinguish the strict form of E. neumani from its former subspecies E. titicacae (Figs. 4A-E). In E. neumani the medial spine is as long as or slightly shorter than the inner spine (0.8-1.0) and in E. titicacae the medial seta is always 1.3 times as long as or even longer than the inner spine. Because of this, it is likely that specimens from Uruguay (SMNK-03107-Fig.
4A) and Río Cruce, Chile (SMNK-11154-Fig. 4D) are assignable to E. titicacae and not to the strict form of E. neumani, although these records would be outside the presumed biogeographic range of E. titicacae (Mercado-Salas et al., 2012; Fuentes-Reinés and Suárez-Morales, 2013). Fuentes-Reinés and Suárez-Morales (2013) proposed the scarce ornamentation of the CR outer margin found in E. titicacae to distinguish it from $E$. neumani s. str. In the former species there are always 3-5 spinules (Figs. 1A, 3C, D) whereas in E. neumani the number of spines covering the outer margin ranges between 7 and 15 (Fig. 3E, F) (see Fuentes-Reinés \& Suárez-Morales, 2013, Fig. 4F). Kiefer's drawings of E. titicacae provided data about the ornamentation of the caudal surface of the P4 intercoxal sclerite, which differs from that of its known congeners but it was not possible to compare this pattern with the type specimens of E. neumani s. str. Records of $E$. neumani s. str. by Reid (1991) from Tres Lagunas, San Luis, Argentina were not included here because illustrations were not available to us.

Eucyclops subciliatus (Dussart, 1984). (Figs. 5, 6)

Material examined: adult female from São Paulo, Brazil (NMHN-IU-2007-3270). Date of collection August 12, 1982; identified by B. H. Dussart; B. Dussart Collection, Muséum National d'Histoire Naturelle, Paris, France.

Female: habitus as in Figure 5A. Average length excluding caudal setae $=1.0 \mathrm{~mm}$. Prosome expanded at first and second somites, representing $60 \%$ of total body length, symmetrical in dorsal view. Pedigerous somites 2-4, with strongly developed subacute lateral pleural projections. Urosome five-segmented (Fig. 5B), relatively elongate; urosomal fringes lightly serrated; posterior margin of anal somite with row of strong spinules. Genital double-somite symmetrical, 1.2 times longer than wide. Seminal receptacle with narrow rounded lateral arms on posterior margin. Telson with short hair-like seta on anal opening, anal operculum serrated (Fig. 5C). Length/width ratio of $\mathrm{CR}=4.7$; hair-like setules present along the inner margin of $\mathrm{CR}$, strong spinules covering 
Table 3. Morphometric data of E. neumani s.str. obtained from: (1) Pesta (1927), (2) Dussart \& Frutos (1986), (3) Uruguay (SMNK-03107), (4) Lago Rupanco, Chile (SMNK-11149), (5) Recife, Brazil (SMNK-02879), (6) Río Cruce, Chile (SMNK-11154), (7) Dussart (MNHN-IU-2010-6807), and (8) E. titicacae from Lake Titicaca, Peru (SMNK-05752, SMNK-05753, and SMNK-05754). Datos morfométricos de E. neumani s.str. obtenido de: 1) Pesta (1927), 2) Dussart \& Frutos (1986), 3) Uruguay (SMNK-03107), 4) Lago Rupanco, Chile (SMNK-11149), 5) Recife, Brasil (SMNK-02879), 6) Río Cruce, Chile (SMNK-11154), 7) Dussart (MNHN-IU-2010-6807) y 8) E. titicacae del lago Titicaca, Perú (SMNK-05752, SMNK-05753, SMNK-05754).

\begin{tabular}{|c|c|c|c|c|c|c|c|c|}
\hline Character & 1 & 2 & 3 & 4 & 5 & 6 & 7 & 8 \\
\hline Length/width CR & 8.0 & 7.5 & - & 5.8 & 7.6 & 7.7 & 8.4 & 6.5 \\
\hline VII/length CR & - & 0.3 & - & 0.3 & 0.30 & 0.3 & 0.3 & 0.3 \\
\hline VII/III setae CR & - & 0.7 & - & 0.6 & 0.7 & 0.8 & 0.6 & 0.7 \\
\hline VI/IV setae CR & 1.3 & 1.2 & - & 1.0 & 1.1 & 1.0 & 1.15 & 1.0 \\
\hline Length/width Enp3 P4 & - & 2 & 2 & 2 & 2.1 & - & 2.2 & 1.9 \\
\hline Inner spine/length Enp3 P4 & - & 1.2 & 1.5 & 1.4 & 1.3 & - & 1.1 & 1.5 \\
\hline Outer spine/length Enp3 P4 & - & 0.9 & 1.0 & 0.9 & 0.9 & - & 0.8 & 1.0 \\
\hline Inner/outer spines Enp3 P4 & - & 1.3 & 1.5 & 1.6 & 1.3 & - & 1.3 & 1.4 \\
\hline Length/width P5 & 1.0 & 1.3 & 1.3 & 1.3 & 1.4 & 2.0 & 1.4 & 1.5 \\
\hline Medial/outer setae P5 & 1.2 & 1.0 & 1.1 & 0.8 & 1.0 & 1.0 & 1.0 & 1.0 \\
\hline Medial seta/inner spine P5 & 1.0 & 0.9 & 1.3 & 1.0 & 1.0 & 1.3 & 0.8 & 1.3 \\
\hline Inner spine/length P5 & 2.5 & 2.4 & 2 & 1.9 & 2.1 & 1.6 & 2.4 & 2.1 \\
\hline
\end{tabular}

$62 \%$ of outer margin of CR. Dorsal seta (VII) short: 0.6 times the length of $\mathrm{CR}$, and 0.7 times as long as outermost caudal seta (III). Ratio of innermost caudal seta (VI)/ outermost caudal seta (III) $=1.1$. Lateral caudal seta (II) inserted at $82 \%$ of CR length. All terminal setae plumose.

Antennule (A1) (Fig. 5D): 12-segmented, reaching middle margin of second prosomite; three distal segments with narrow hyaline membrane. Armament per segment as follows: 1(8s), 2(4s), $3(2 s), 4(6 s), 5(1 s), 6(1 s+1 s p), 7(2 s), 8(3 s), 9(1 s)$, $10(2 s), 11(2 s), 12(7 s)$. Two rows of spines on first segment, first row with small spinules and second row with stronger and longer spines.
Antenna (A2) (Fig. 5E, F): basis (2s + Exp), plus three-segmented Enp (armature: 1s, 8s, 7s). Basis ornamentation (sensu Alekseev and Defaye, 2011) as follows: on frontal surface: N1(3), N4(4), N6(8), N17(8); on caudal surface, N7(4), N8(7), N9 + 10(8), N11(8), N12(7), N13(10), N15(3).

Mouthparts: not observable in slides examined.

P1-P4: endopod and exopods of all swimming legs three-segmented. Armature formula as in Table 1.

P1 (Fig. 6A): intercoxal sclerite with cluster of tiny spinules close to apical margin on each side of frontal surface; distal margin with two rounded 


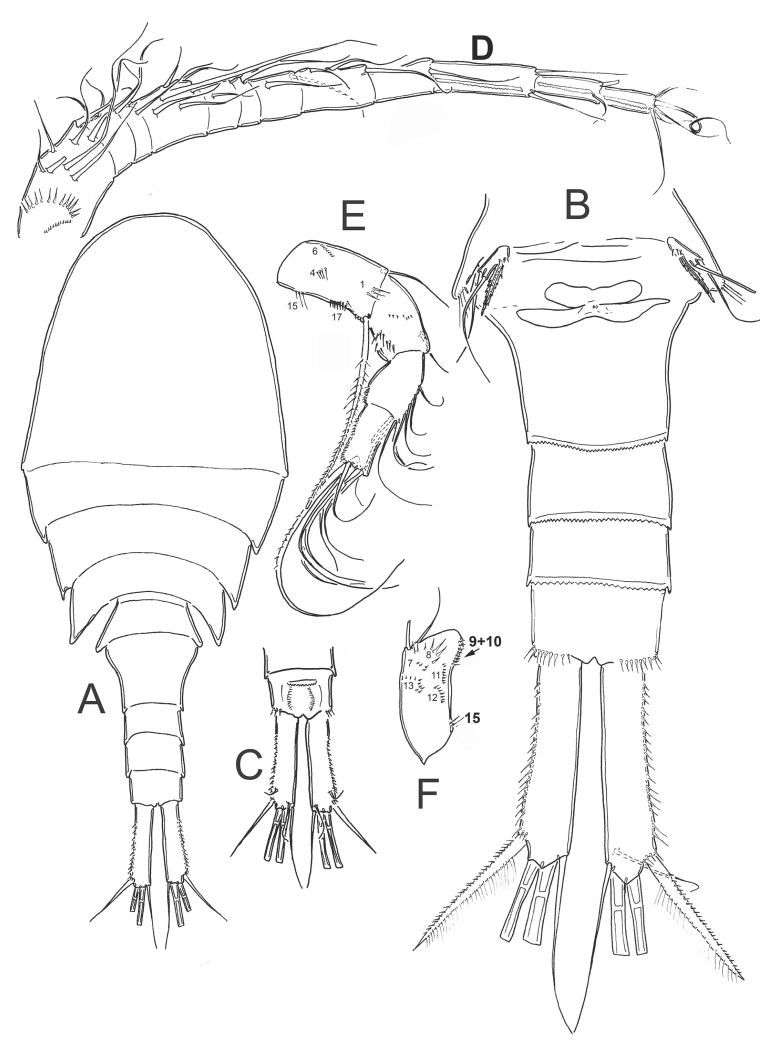

Figure 5. Eucyclops subciliatus (Dussart, 1984), adult female (MNHN-IU-2007-3270) from Sâo Carlos, Sâo Paulo, Brazil: A. habitus, dorsal; B. urosome, ventral; C. anal somite, dorsal; D. antennule; E. antenna, frontal view; F. antenna basipodite, caudal view. Eucyclops subciliatus Dussart, 1984, hembra adulta (MNHN-IU-2007-3270) de Sâo Carlos, Sâo Paulo, Brazil. A. hábito, vista dorsal; B. urosoma, vista ventral; $C$. somita anal, vista dorsal; D. anténula; E. antena, vista frontal; $F$. basipodito de la antena, vista caudal.

chitinized projections. Coxa with strong, biserially setulated inner coxal seta. Coxa with row of long setules along outer margin and transverse row of few spinules on middle margin, close to outer margin. Basipodal spine stout, reaching middle margin of Enp3, 0.7 times as long as Enp. Length/width ratio Enp3P4 $=1.2$; proportion of apical spine/length of Enp3 $=0.9$. Exp1 with row of small spinules on middle margin (arrowed in Fig. 6A).

P2 (Fig. 6B): intercoxal sclerite with two rows of tiny spinules along middle margin of caudal surface. Distal margin of intercoxal sclerite with two low, rounded, chitinized projections. Coxa

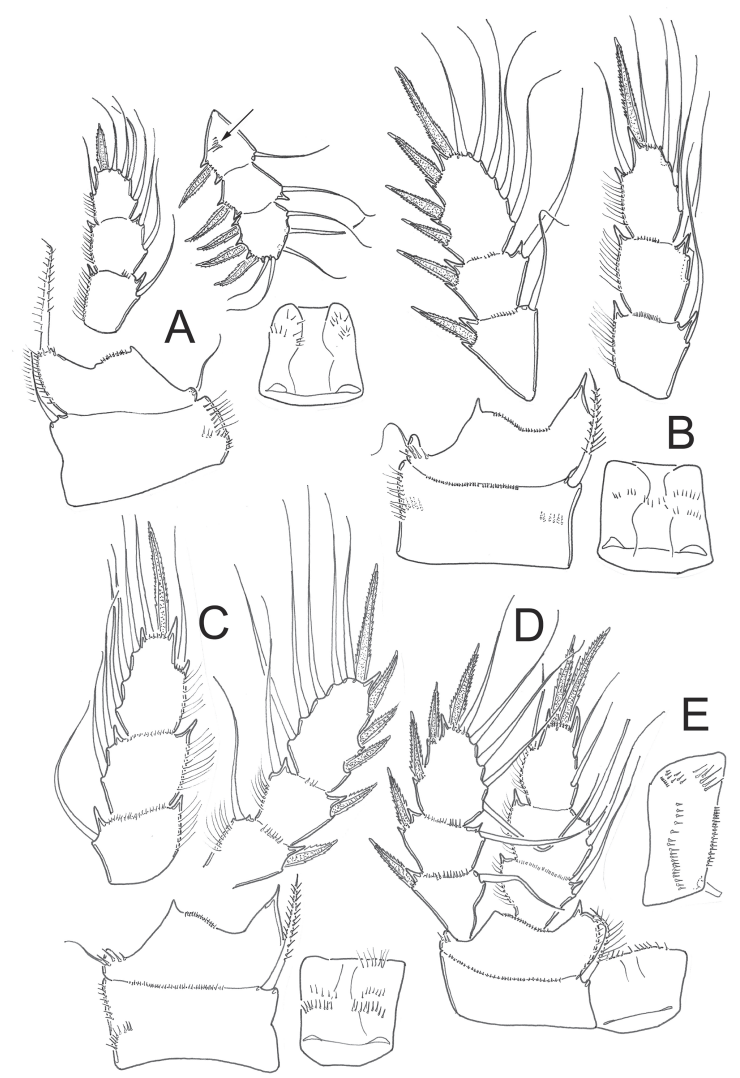

Figure 6. Eucyclops subciliatus (Dussart, 1984), adult female (MNHN-IU-2007-3270) from Sâo Carlos, Sâo Paolo, Brazil: A. leg 1; B. leg 2, rami separately illustrated; C. leg 3idem; D. leg 4; E. coxa, caudal view. Eucyclops subciliatus Dussart, 1984, hembra adulta (MNHN-IU-2007-3270) de Sâo Carlos, Sâo Paulo, Brazil. A. pata 1; B. pata 2, ramas ilustradas por separado; C. patas 3, ramas ilustradas por separado; D. pata 4; E. coxa de pata 4 , vista caudal.

with strong, biserially setulated inner coxal seta. Coxa with row of hair-like setules along outer margin. Small spinules at insertion of basipod on frontal surface. Caudal surface with two transverse rows of small spinules on middle margin: the first close to outer margin and the other close to inner margin. Small spinules on Exp at insertion of spines, with regular setae on Exp and Enp. P3 (Fig. 6C): caudal surface of intercoxal sclerite with three rows of hair/spinules, all rows with small gaps at the center: the first close to the apical margin, bearing 14 hair-like setules; the second, a transverse row of 14 tiny spinules along medial margin; and the third one a transverse row 
of 18 spinules located next to second row. Distal margin of intercoxal sclerite with two slightly rounded projections. Coxa with strong biserially setulated coxal seta, coxa with spinules along outer margin, tiny spinules at insertion of basipod. Unmodified setae on Exp and Enp, with Enp segments slightly expanded.

P4 (Fig. 6D, E): intercoxal sclerite with row I observable, represented by seven small spinules on each side, with a small gap between them. Inner coxal spine with heteronomous ornamentation: basally, with long hair-like setules, and distally, with spine-like setules; outer edge with distal spine-like setules. Caudal coxal surface with spinule formula $\mathrm{A}+\mathrm{H}, \mathrm{B}, \mathrm{C}+\mathrm{D}, \mathrm{E}, \mathrm{G}$. Length/width ratio of Enp3 P4 $=1.5$; length ratio

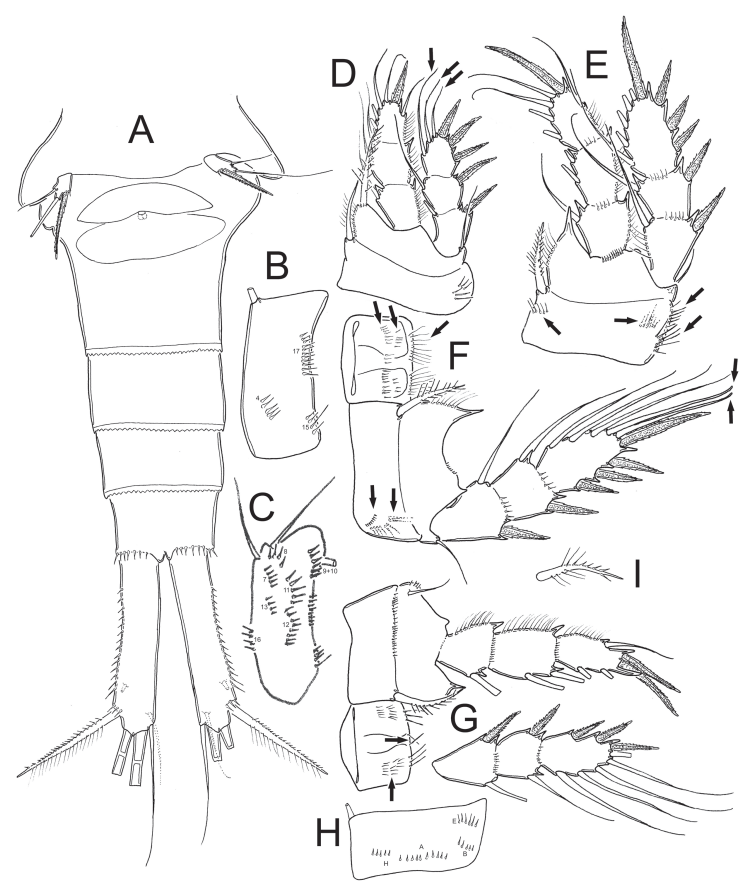

Figure 7. Eucyclops pseudoensifer (Dussart, 1984), holotype adult female (MNHN-IU-2007-3117) from Laguna Macabaji, Venezuela: A. urosome, ventral; B. antennary basipodite, frontal view; C. antennary basipodite, caudal view; D. leg 1; E. leg 2; F. leg 3; G. leg 4; H. Coxa, caudal view; I. inner coxal spine. Eucyclops pseudoensifer Dussart, 1984, hembra adulta, holotipo (MNHN-IU-2007-3117) de Laguna Macabaji, Venezuela. A. urosoma, vista ventral; B. basipodito de la antena, vista frontal; $C$. basipodito de la antena, vista caudal; D. pata 1; E. pata 2; F. pata 3; G. pata 4; H. coxa, vista caudal; I. espina coxal interna. of inner/outer spines of Enp3 P4 $=1.2$; length ratio of inner spines of Enp3 P4/length Enp3 P4 $=1.4$; length ratio of outer spine of Enp3 P4/length Enp3 P4 = 1.1. Lateral seta of Enp3 P4 inserted at $70 \%$ of segment length. Unmodified setae on Enp and Exp. Enp1 and 2 expanded (wider than long).

P5 (Fig. 5B): free segment subrectangular, twice as long as wide; bearing strong inner spine and two setae; medial seta 1.2 times longer than outer seta and 2 times longer than inner spine. Inner spine 1.6 times as long as segment.

Remarks: This species is easily recognizable from its congeners by the presence of setules along the inner margin of the furca; this charac-

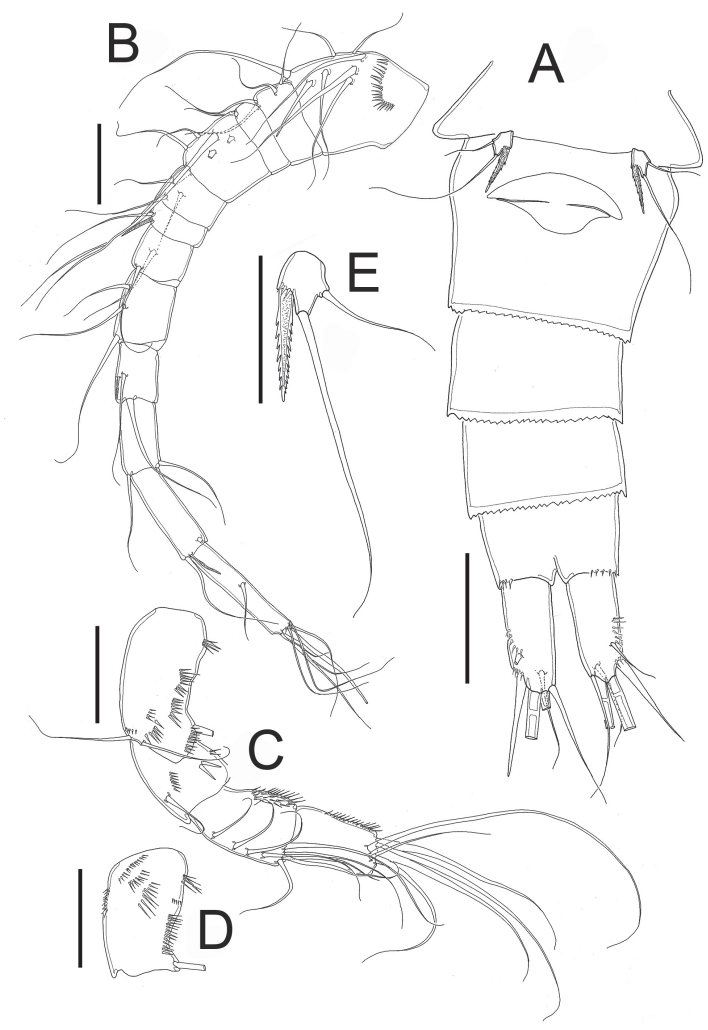

Figure 8. Eucyclops pseudoensifer (Dussart, 1984), allotype adult male (MNHN-IU-2007-3117) from Laguna Macabaji, Venezuela: A. antenna, frontal view; B. legs 5 and 6 , ventral view; C. P1; D. P2; E. P4. Eucyclops pseudoensifer Dussart, 1984, macho adulto, alotipo (MNHN-IU-2007-3117) de Laguna Macabaji, Venezuela. A. antena, vista frontal; B. patas 5 y 6 , vista ventral; C. pata1; D. pata 2; E. pata 4. 
ter is not found in any other American species of Eucyclops, and it is shared with the African $E$. ciliatus only. The ornamentation pattern of the frontal and caudal surfaces of the antennary basis was included in Table 2 in order to compare it with its closest congeners.

\section{Eucyclops pseudoensifer (Dussart, 1984)} (Figs. 7-8)

Material examined: holotype adult female from Laguna Macabaji, Venezuela; specimen dissected (NMNH-IU-2007-3117), September 5, 1980, by Evelyn Zoppi. Allotype adult male specimen dissected (NMNH-IU-2007-3116), same collection date and collector. B.H. Dussart Collection (Muséum National d'Histoire Naturelle, Paris, France).

Female: Average body length excluding caudal setae $=0.8 \mathrm{~mm}$. Prosome expanded at first and second somites, representing $58 \%$ of total body length, symmetrical in dorsal view. Five segmented urosome, relatively elongated; posterior margin of telson with one row of strong spinules. Genital somite symmetrical, 1.1 times longer than wide. Seminal receptacle as in serrulatus-group (Fig. 7A). Anal operculum slightly rounded. Length/width ratio of $\mathrm{CR}=4.3$; spinules along outer margin, increasing in size as they approach the apical margin, covering $63-65 \%$ of length of furca. Dorsal seta (VII) short: $0.3-0.4$ times the length of CR and, 0.4-0.6 times as long as outermost caudal seta (III). Ratio of innermost caudal seta (VI)/outermost caudal seta (III) $=1.1-1.2$. Lateral seta (II) inserted at $78 \%$ of furca. All terminal setae plumose.

Antennule (A1): 12- segmented, not reaching posterior margin of cephalothorax; last three segments with narrow hyaline membrane. Armament per segment as follows: 1(8s), 2(4s), 3(2s), $4(6 s), 5(3 s) 6(1 s+1 s p), 7(2 s), 8(3 s), 9(2 s+1 a e)$, $10(2 \mathrm{~s}), 11(2 \mathrm{~s}), 12(7 \mathrm{~s})$.

A2 (Figs. 7B, C): Basis (2s + Exp), three-segmented Enp (armature: 1s, 9s, 7s). Basis ornamentations sensu Alekseev and Defaye (2011) as follows: on frontal surface, N4(5) N15(4); on caudal surface, N7(5), N8(4), N9 + 10(8),
N11(5), N12(9), N13(4), N15(4), N16(4), N17(8) (see Suárez-Morales \& Walsh, 2009, Fig. 6A).

Mouthparts: not observable in slides.

P1-P4: endopod and exopods of all swimming legs three-segmented. Armature formula as in Table 1.

P1 holotype (Fig. 7D): coxa with strong biserially-setulated inner coxal seta. Basipodal spine not reaching medial margin of Enp3, 0.6 times as long as Enp. Length/width ratio of Enp4 = 1.4; apical spine as long as segment (Enp3). Holotype with abnormal setation pattern on Exp3, as outlined by Dussart (1984), with only three inner setae (arrow in Figure 7D). Paratype (Suárez-Morales \& Walsh, 2009, Fig. 6B): intercoxal sclerite with a group of strong and relatively long spinules on each side of frontal surface and distal margin with two rounded chitinized projections. Coxa with strong and biserially-setulated inner coxal seta. Basipodal spine not reaching medial margin of Enp3, 0.8 times as long as Enp. Length/width ratio Enp3 = 1.4; apical spine as long as segment (Enp3). Paratype with the normal pattern of setation on Exp3, bearing five setae on inner margin.

P2 holotype (Fig. 7E): coxa with strong biserially setulated inner coxa seta. Coxa with two rows of long hair spinules along outer margin, one below the other (arrowed in Fig. 7E). Caudal surface of coxa with two transversal rows of long spinules in middle margin: one close to outer margin and the second close to inner margin (arrowed in Fig. $7 \mathrm{E})$. Length/width ratio of Enp3 = 1.6: apical spine 1.5 times as long as segment (Enp3). Unmodified setae on Enp and Exp. Paratype (Suárez-Morales \& Walsh, 2009, Fig. 6B): frontal surface of intercoxal sclerite with a group of hairs close to apical margin on each side of sclerite. Coxa with strong biserially setulated inner coxa seta. Coxa with one row of spinules along outer margin. Length/width ratio of Enp3 = 1.7; apical spine 1.4 times as long as segment (Enp3). Unmodified setae on Enp and Exp.

P3 holotype (Fig. 7F): caudal surface of intercoxal sclerite ornamented with three spinule rows: the first bearing long hairs with small medial gap; second row with short, strong spinules; third one furnished with strong, short spinules (all arrowed 
in Fig. 7F). Caudal surface of coxa with two rows of spinules close to outer margin: the first bearing long spinules and the second (below the first) armed with tiny spinules (both arrowed in Fig. 7F). Length/width ratio of Enp3 $=2.0$, apical spine 1.2 times as long as segment (Enp3). Two most apical setae of Exp modified (arrowed in Fig. 7F).

Paratype (Suárez-Morales \& Walsh 2009, Fig. $6 \mathrm{D})$ : frontal surface of intercoxal sclerite with a group of hair-like setules close to apical margin on each side of sclerite. Coxa with strong biserially setulated inner coxa seta. Coxa with one row of small, strong spinules along outer margin. Length/width ratio of Enp3 $=2.0$, apical spine 1.3 times as long as segment (Enp3). Unmodified setae on Enp and Exp.

P4 holotype (Figs. 7G-I): intercoxal sclerite with only row I observable on caudal surface, represented by five slender, elongated spinules on each side, separated by a gap (arrowed in Fig. $7 \mathrm{G}$ ); frontal surface with a group of 19 hairs arranged in a circle close to apical margin on each side of sclerite (arrowed in Fig. 7G). Inner coxal spine with heterogeneous ornamentation: basally, with long hair-setules, and distally, with spinules; outer edge with four hair setules set basally and distally with one strong spinule and medial gap (arrowed in Fig. 7I). Frontal surface of coxa with row of tiny spinules at insertion of basipod, caudal surface of coxa with spinule formula: $\mathrm{A}+\mathrm{B}+\mathrm{E}+\mathrm{H}$ (rows $\mathrm{C}+\mathrm{D}-\mathrm{G}, \mathrm{J}$ not observed). Length/width ratio of Enp3 $=2.0$; length ratio of inner spine/outer spine of Enp3 = 1.2; length ratio of inner spine/length of Enp3 = 1.2 , length ratio of outer spine/length of Enp3 = 1.0. Lateral seta of Enp3 inserted at $72 \%$ of the total length of segment. Unmodified seta on Enp and Exp. Paratype (Suárez-Morales \& Walsh, 2009, Fig. 7A, C): intercoxal sclerite with only row I drawn, represented by seven long hairs on each side, separated by gap. Inner coxal seta with uniform ornamentation. Length/width ratio of Enp3 $=2.3$; length ratio of inner/outer spines of Enp3 $=1.2$; length ratio of inner spine/length of Enp3 $=1.2$, length ratio of outer spine/length of Enp3 $=1.0$. Lateral seta of Enp3 inserted at $71 \%$ of the total length of segment. Unmodified setae on Enp and Exp.

P5 holotype (Fig. 7A): free segment subrectan- gular, 1.7 times as long as wide; bearing one inner spine and two setae; medial seta 2.1 times longer than outer seta and 1.3 times longer than inner spine. Inner spine 2.6 times longer than segment. Paratype (Suárez-Morales \& Walsh, 2009 Fig. 5B): free segment subrectangular, 1.6 times longer than wide; bearing one strong inner spine and two setae; medial seta 2.3 times longer than outer seta and 1.3 times longer than inner spine. Inner spine 2.7 times longer than segment.

Remarks: This species was recently redescribed by Suárez-Morales and Walsh (2009) using type material (paratypes). Most of the characters used in the current taxonomy of Eucyclops were considered in the redescription, except for the ornamentations of the intercoxal sclerites (caudal surface) of the third and fourth legs and the ornamentation of the fourth coxa and inner coxal seta; these details are first described herein. We found some differences between the paratypes and the holotype specimen. The holotype shows the anomalous setation of leg 1 described by Dussart (1984a), in which Exp3 bears only 3 setae instead of the normal pattern of 5 setae (Suárez-Morales \& Walsh, 2009) in the paratype. The intercoxal sclerite of the fourth swimming leg has an additional difference: in the holotype specimen, row I has long spinules whereas in the paratype this row bears long and slender hair-like elements. In the Mexican material examined we found a particular pattern in the intercoxal sclerites of legs 3 and 4 , with row I of P4 bearing hair-like elements; also, P3 caudal rows I-III are always represented by hair-like elements as well, but when Row I of P4 bears spinules, at least one of the three rows of $\mathrm{P} 3$ has spinules. If we assume that this pattern is general among the American Eucyclops, the holotype and paratypes of E. pseudoensifer represent an exception to this rule. In the holotype the intercoxal sclerite follows the pattern described, with three rows on the caudal surface, one row with fine and long hair-like elements and the other two with strong but small spinules. The ornamentation of the intercoxal sclerites has been used in several genera of cyclopid copepods (Cyclops, Acanthocyclops, Mesocyclops, Microcyclops) for the separation of closely related species (Einsle, 1985; Rocha, 1998), but most attention has 


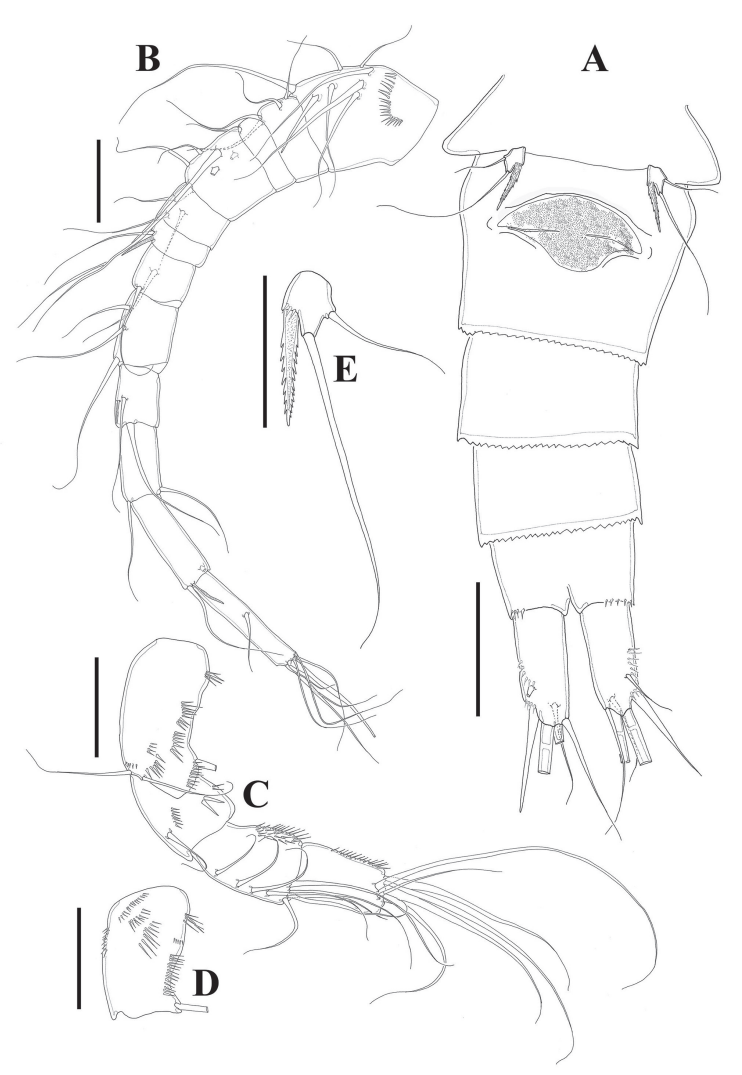

Figure 9. Eucyclops breviramatus (Löffler, 1963), syntypic female specimen from Ecuador: A. urosome, ventral view; B. antennule, frontal view; C. antenna; D. antennary basis, caudal view; E. P5, ventral view. Eucyclops breviramatus Löffler, 1963, especimen sintípico, hembra de Ecuador. A. urosoma, vista ventral; $B$. anténula, vista frontal; $C$. antena; $D$. basipodito de la antena, vista caudal; E. pata 5, vista ventral.

been given to the fourth leg. The evaluation of the sclerite ornamentation as a taxonomically valuable character to distinguish species of Eucyclops should be expanded to include all swimming legs.

Our results indicate that E. pseudoensifer does not belong to the serrulatus-group because it lacks rows N1 and N2 on the frontal surface of the antennal basis, a character pointed out by Alekseev \& Defaye (2011) as distinctive of the serrulatus-group. Thus, this species can be easily distinguished from its American congeners with a similar CR: E. bondi, E. pectinifer, E. prionophorus, E. cuatrocienegas and E. chihuahuensis) by characters of the antennary basis. Another Ameri- can species that is not assignable to the serrulatus-group is $E$. conrowae, which clearly differs from E. pseudoensifer by its remarkably long dorsal caudal seta (as long as or slightly shorter than the furca) while in E. pseudoensifer the dorsal seta is just 0.3-0.4 as long as the furca. In addition, the presence of strongly modified setae on the Enp and Exp of P4 is a distinctive character present in E. conrowae vs. normal setae in $E$. pseudoensifer.

Eucyclops breviramatus Löffler, 1963 (Figs. 9, 10)
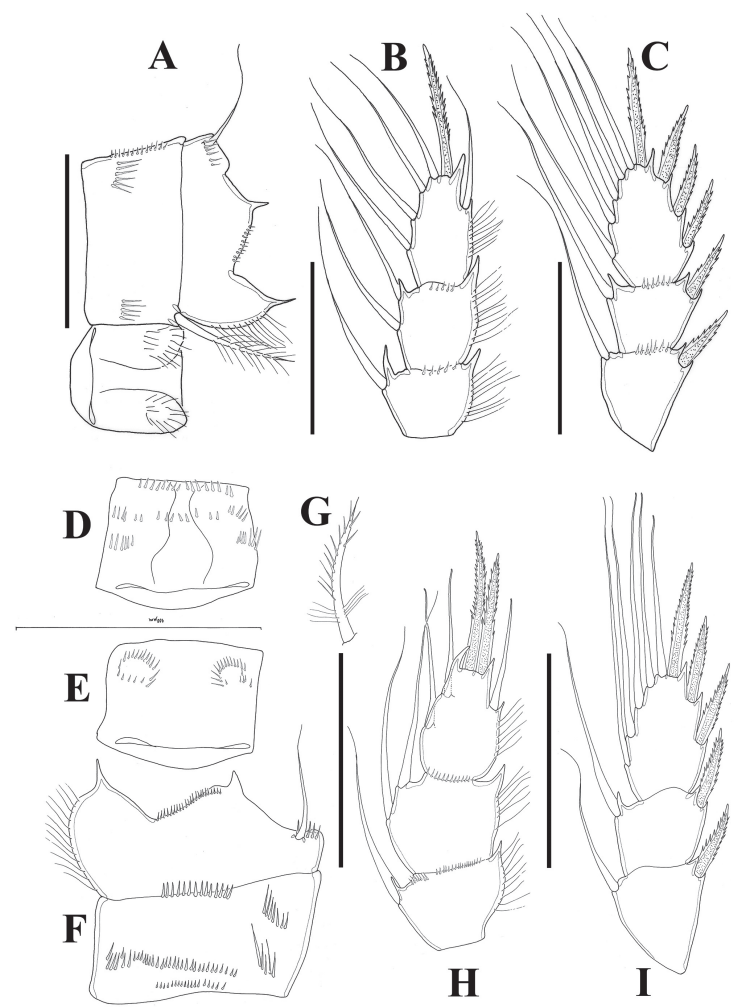

Figure 10. Eucyclops breviramatus (Löffler, 1963), syntypic female specimen from Ecuador: A. coxa and basis of P3, B. enp of the same, C. exp of the same; D. intercoxal sclerite of the same, caudal view; E. P4 intercoxal sclerite, caudal view; F. coxa and basis of the same; G. inner coxal spine of the same; $\mathrm{H}$. enp of the same; I. exp of the same. Eucyclops breviramatus Löffler, 1963, especimen sintípico hembra, de Ecuador. A. coxa y base de pata P3, B. endopodito de pata 3, C. exopodito de pata 3; D: esclerito intercoxal de pata 3, vista caudal; E. esclerito intercoxal de pata 4, vista caudal; $F$. coxa y base de pata 4; $G$ espina coxal interna de pata 4; H. endopodito de pata 4; I. exopodito de pata 4. 
Material examined: syntypic specimens from H. Löffler's collection NHMW22245 (q), NHMW22247 (ㅇ), NHMW22250 (1, 1今̂), collected by Herrn Prescott from Papallacta, Napo Province, Ecuador. Date: May 1st, 1958. No slide or specimen identified as the holotype; slide NHMW22250 includes 299 of Metacyclops mendocinus.

Female: Body length excluding caudal setae = $1164 \mu \mathrm{m}$ (measurement taken from Löffler, 1963). Proportions between prosome and urosome not available (all specimens were dissected). 5-segmented ursome, not elongated (Fig. 9A); telson posterior margin with row of spinules. Genital double-somite symmetrical, as long as wide. Seminal receptacle not clearly defined. Anal operculum smooth, rounded. Length/width ratio of CR ranging from 2.37 to $2.61(\mathrm{x}=2.46 \mathrm{~m}, \mathrm{n}=6)$; spinules on outer margin about the same size, covering $40 \%$ of the total length of the furca. Dorsal seta (VII) about 0.8 times as long as CR and $0.8-0.9$ times as long as outermost caudal seta (III). Ratio of innermost caudal seta (VI)/outermost caudal seta (III) $=1.0-1.1$. Lateral seta (II) inserted at $62 \%$ of CR length.

Antennule (A1) (Fig. 9B): 12-segmented, distal three segments with narrow hyaline membrane. Armament per segment as follows: 1(8s), 2(4s), $3(1 s), 4(6 s), 5(3 s), 6(1 s+1 s p), 7(2 s), 8(3 s), 9(2 s$ +1ae), 10(2s), 11(2s + 1ae), 12(8s).

Antenna (A2) (Fig. 9C, D): Basis (2s+Exp), 3-segmented Enp (1s, 8s, 6s). Basis ornamentations confirmed in slides NHMW22247 and NHMW22250: frontal surface N3(5-8), N4(6-7), N5(12-15), N6(4), N15(5-7); on caudal surface, N7(5), N8(6-7), N9 + N10(9), N11(6--7), N12(9), N14(4), N18(5--6).

Mouthparts, P1 and P2 not observable in examined slides.

P3 (Fig. 10A-C): caudal surface of coxa, basis, and intercoxal sclerite not observable. Frontal surface of coxa ornamented with rows A, B, and $C$; frontal surface of intercoxal sclerite with fine setules arranged in circular pattern on each side. Coxa with strong, biserially setulated inner coxal

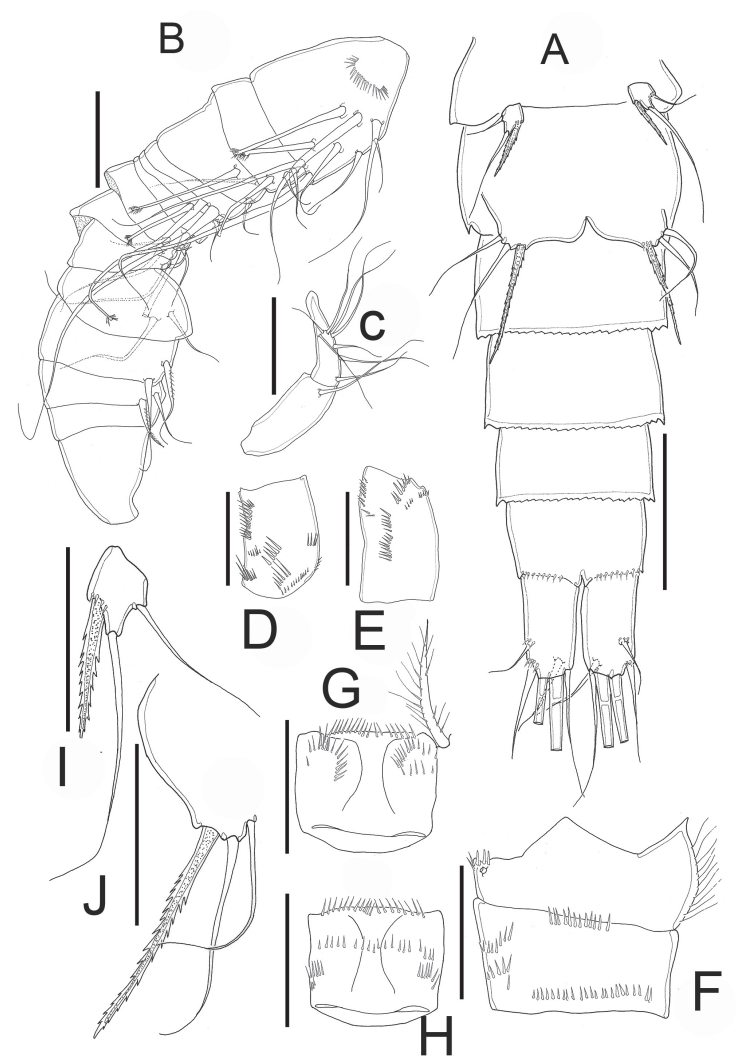

Figure 11. Eucyclops breviramatus (Löffler, 1963), syntypic male specimen from Ecuador: A. urosome, ventral view; B. antennule; C. distal segments of antennule; D. antennary basis, frontal view; E. the same, caudal view; F. P4 coxa and basis; G. P4 intercoxal sclerite, caudal; H. coxa and basis of same; I. leg P5, ventral view; J. leg 6, ventral view. Eucyclops breviramatus Löffler, 1963, especimen macho sintípico de Ecuador. A. urosoma, vista ventral; $B$. anténula; $C$. segmentos distales de la anténula; D. base de la antena, vista frontal; E: base de la antena, vista caudal; F. coxa y base de pata 4; $G$ esclerito intercoxal de la pata 4, vista caudal; $H$. coxa y basis de la pata 4; I. pata P5, vista ventral; J. pata 6, vista ventral.

seta. Length/width radio of Enp3 = 1.8; apical spine 1.2 times as long as segment (Enp3). Unmodified setae on Exp and Enp.

P4 (Fig. 10D-I): caudal surface of coxa with rows $\mathrm{A}, \mathrm{B}, \mathrm{C}+\mathrm{D}, \mathrm{E}$, and $\mathrm{H}$. Frontal surface of intercoxal sclerite with small spinules arranged in circular pattern on each side. Caudal surface of intercoxal surface with rows I, II, and III bearing spinules: row I continuous, bearing 15 spinules; row II with two small gaps dividing the row into three groups; row III with six spinules on each 
side, not continuous. Intercoxal spine with heterogeneous ornamentation: basally, with long hair-like setules, and distally, with spinules; outer edge with four hair-like setules set basally and distally, with two spinules, gap in the middle margin. Length/width ratio Enp3 = 1.5; length inner spine/outer spine Enp3 $=1.2$; length inner spine/length of Enp3 = 1.25; length outer spine/length of Enp3 = 1.1. Lateral seta of Enp3 inserted at $68 \%$ of the total length of segment. Three most apical setae of Exp3 modified.

P5 (Fig. 9E): one subrectangular free segment, 1.3 times as long as wide, bearing one inner spine and two setae; medial seta 2.1 times longer than outer seta and 2.7 times longer than inner spine. Inner spine 1.9 times longer than segment.

Male: body length excluding caudal seta $980 \mu \mathrm{m}$ (from Löffler, 1963). Proportions between prosome and urosome not available; urosome 6-segmented (Fig. 11A). CR 2-2.4 times longer than wide; medial margin naked, spinules at insertion of caudal seta (III) and outermost terminal causal seta (III). Dorsal seta (VII) as long as $\mathrm{CR}$ and, slightly longer than outermost caudal seta (III). Lateral caudal seta (II) inserted at $75 \%$ of caudal ramus.

Antennule (Fig. 11B, C): 16-segmented, armature per segment as follows: $1(7 \mathrm{~s}+2 \mathrm{~ms}), 2(4 \mathrm{~s})$, $3(1 \mathrm{~s}+1 \mathrm{~ms}), 4(1 \mathrm{~s}+1 \mathrm{~ms}), 5(1 \mathrm{~s}+1 \mathrm{~ms}), 6(1 \mathrm{~s})$, 7(2s), 8(1S), 9(2s), 10(2s), 11(2s), 12(2s), 13(0), $14(0), 15(1 \mathrm{~s}), 16(8 \mathrm{~s})$.

Antenna (Fig. 11D, E): basis with spinule groups: on frontal surface, N3(5), N4(6),N5(11), N6 (4), 15(7), 17(14), 18(6), and on caudal surface, N7(7), N8(9), N9 + N10(9), N11(6), N12(9).

P4 (Fig. 11F-H): as in female.

P5 (Fig. 11I): Free segment subrectangular, 2.5 times longer than wide, bearing one spine and two setae; medial seta longer than outer seta (about 1.6 times) and inner spine (1.9 times). Inner spine slightly shorter than outer seta.

P6 (Fig. 11J): represented by a small, low plate adjacent to lateral margin of genital somite, armed with one strong inner spine and two unequally-sized setae. Inner seta not reaching medial margin of fourth urosomite; inner spine 1.1 times longer than medial seta and 1.3 times longer than outer seta.

Remarks. Eucyclops breviramatus was described by Löffler (1963) from material collected in Ecuador; was subsequently reported in Mexico, but Mexican records of this species are probably assignable to one of the species recently described by Mercado-Salas et al., 2016).

Our observations indicate that E. breviramatus should not be considered a member of the $E$. serrulatus-complex as it lacks rows N1 and N2 on the antennary basis, which is a distinctive character present only in species of this group (Alekseev et al., 2006; Alekseev \& Defaye, 2012).

\section{DISCUSSION}

In 1927 Otto Pesta described Eucyclops neumani from Argentina; this species closely resembles the cosmopolitan E. macrurus (Sars, 1863) and $E$. serrulatus, but clearly differs from both. After its original description, E. neumani has been recorded in Argentina, Brazil, Chile, Peru, and Uruguay (Reid, 1985, 1991; Dussart \& Frutos, 1986; Rocha \& Botelho, 1998; Dussart \& Defaye, 2006). Friedrich Kiefer (1957) described the subspecies Eucyclops neumani titicacae from Lake Titicaca, Peru; it has been recorded thereafter in Venezuela (Lake Valencia), Bolivia and Peru (Lake Titicaca) (Reid, 1985; Del Río \& Valdivia, 1989; Silva, 2008), and recently from Colombia, an illustrated record in which $E$. titicacae is recognized as an independent species (Fuentes-Reinés \& Suárez-Morales, 2013).

One of the main researchers of the freshwater copepod fauna worldwide, particularly of the tropical regions, was the French copepodologist Bernard H. Dussart. His works revealed much of the rich tropical biodiversity and created a new stimulus for the study of freshwater copepods (Defaye \& Vaupel Klein, 2011). During the course of his long career, he described many freshwater cyclopoid species of Eucyclops from South America; Eucyclops pseudoensifer Dussart, 1984 and E. subciliatus Dussart, 1984 are among them. The former was collected from 
the Venezuelan Andes. This taxon resembles the Chilean E. ensifer (Kiefer, 1936), but differs in the structure of the female fifth leg and male sixth leg. After its original description, E. pseudoensifer was recorded in Mexico, Colombia, and Venezuela (Reid, 1985; Gaviria, 1994; Grimaldo-Ortega et al., 1998; Mercado-Salas, 2009). In the same year, Dussart (1984a) described another species of Eucyclops from Brazil: E. subciliatus, collected from a pond near Sâo Carlos, which closely resembled the African E. ciliatus (G.O. Sars, 1909) for its sharing of caudal rami furnished with hair-like setules on the inner margins - a rare character in the genus - and $E$. serrulatus as described by Smith and Fernando (1980) from Cuba. This species was recorded only from Brazil and Argentina (Dussart \& Frutos, 1986; Rocha \& Botelho, 1998), but local and regional records of E. serrulatus should be revised in the light of the present redescription. Eucyclops pseudoensifer was redescribed by Suárez-Morales and Walsh (2009) using current upgraded standards and an examination of the paratypes; it was found to resemble both the South American E. silvestrii (Brian, 1927) and the North American E. chihuahuensis (a presumed Mexican endemic; Suárez-Morales \& Walsh, 2009), but had greater affinity with to the latter. Because of the lack of rows N1 and N2 on the antennary basis, this species is not assignable to the E. serrulatus species-group (Mercado-Salas et al., 2016).

The available descriptions of both $E$. neumani neumani and E. subciliatus are in need to be completed in detail to allow the evaluation of complementary characters including the complete ornamentation of the antennary basis and the intercoxal sclerites. Despite the fact that they are easily distinguishable from related species, it is not possible to reliably include them in any of the main species-groups of Eucyclops and establish their affinities. There are still several taxonomic problems in the genus that certainly deserve further study.

\section{ACKNOWLEDGEMENTS}

We gratefully acknowledge the support, confidence, and advice of Dr. Danielle Defaye, Muséum National d'Histoire Naturelle, Paris, who kindly allowed us to examine the material deposited in the Museum's collections. We also thank Dr. Hans Walter Mittmann, Staatliches Museum für Naturkunde, Karlsruhe, Germany, who granted permission to examine the unpublished original drawings by F. Kiefer of Eucyclops neumani neumani and E. neumani titicacae. We thank Dr. Peter C. Dworschak -Naturhistorisches Museum Wien- who allowed us to examine the material of E. breviramatus from the Löffler Collection. This work is part of the first author's (NFM-S's) PhD thesis developed at El Colegio de la Frontera Sur (ECOSUR), Mexico and supported by CONACyT project 133404-Investigación Científica Básica 2009. We warmly dedicate this contribution to the memory of María Rosa Miracle, who was keenly interested in the taxonomy and biogeography of the European Eucyclops. She was a tireless promoter of research on freshwater zooplankton, and a cherished colleague.

\section{REFERENCES}

ALEKSEEV, V., H. J. DUMONT, J. PENSAERT, D. BARIBWEGURE \& D. VANFLETEREN JR. 2006. A redescription of Eucyclops (Fischer, 1851) (Crustacea: Copepoda: Cyclopoida) and some related taxa, with a phylogeny of the E. serrulatus-group. Zoologica Scripta, 35: 123-147. DOI: 10.1111/j.1463-6409.2006.00223.x

ALEKSEEV, V. \& D. DEFAYE. 2011. Taxonomic differentiation and world geographical distribution of the Eucyclops serrulatus group (Copepoda, Cyclopidae, Eucyclopinae). In: Studies on freshwater Copepoda: a volume in honour of Bernard Dussart. Defaye D., Suárez-Morales E., von Vaupel Klein J.C. (eds.): 16: 1-72. Crustaceana Monographs, Koninklijke Brill NV, Leiden, Netherlands. DOI: $10.1163 / 9789004188280003$

DE LOS RÍOS, P., R. RIVERA \& J. J. MORRONE. 2010. Cyclopoids (Crustacea: Copepoda) reported from Chilean inland waters. Boletín de Biodiversidad de Chile, 2: 10-20.

DEFAYE, D. \& B. H. DUSSART. 1988. Compléments a la faune des Crustacés Copépodes des eaux intérieures de Guyane Francaise. Revue d'Hydrobiologie Tropicale, 71 (1): 
81-91.

DEFAYE, D \& J. C. VAUPEL KLEIN. 2011. Bernard Dussart 17 August 1922- November 1, 2008. In: D. Defaye, E. Suárez-Morales E. \& J.C. von Vaupel Klein (eds.): 16, 1-39. Studies on freshwater Copepoda: a Volume in honour of Bernard Dussart. Crustaceana Monographs, Koninklijke Brill NV, Leiden, Netherlands.

DEL RÍO, M. L. \& V. R. VALDIVIA. 1989. Copépodos dulceacuícolas de vida libre en el Perú. Familia Cyclopidae, Orden Cyclopoida. Boletín de Lima, 63: 71-80.

DUSSART, B. H. 1984. Some Crustacea Copepoda from Venezuela. Hydrobiologia, 113: 25-67.

DUSSART, B. H 1984a. Sur quelques Copépodes d'Amérique du Sud. IV. Revista Brasileira de Biología, 44 (3): 255-265.

DUSSART, B. H. \& S. M. FRUTOS. 1986. Sur quelques Copépodes d'Argentine 2. Copépodes du Paraná Medio. Revue d'Hydrobiologie Tropicale, 19 (3-4): 241-262.

DUSSART, B.H. \& D. DEFAYE. 2006. World Directory of Crustacea Copepoda of Inland Waters II-Cyclopiformes. Backhuys Publishers, Leiden, Netherlands: 334.

EINSLE, U. 1985. A further criterion for the identification of species in the genus Cyclops s. str. (Copepoda, Cyclopoida). Crustaceana, 49 (3): 299-309.

FUENTES-REINÉS，J. \& E. SUÁREZ-MORALES. 2013. First record of the freshwater copepod Eucyclops titicacae Kiefer, 1957, new rank (Copepoda, Cyclopoida) in Colombia. Biota Neotropica, 13 (4): 1-8. DOI: 10.1590/S1676-06032013000400011

GAVIRIA, S. 1994. Los copépodos (Arthropoda, Crustacea) de vida libre de las aguas continentales de Colombia. Revista de la Academia Colombiana de Ciencias Exactas Físicas y Naturales, 19: 361-385.

GAVIRIA, S. \& N. ARANGUREN. 2007. Especies de vida libre de la subclase Copepoda (Arthropoda, Crustacea) en aguas continentales de Colombia. Biota Colombiana, 8: 53-68.

GRIMALDO-ORTEGA, D., M. ELÍAS-GUTIÉRREZ, M. CAMACHO-LEMUS \& J.
CIROS-PÉREZ. 1998. Additions to Mexican freshwater copepods with the description of the female Leptodiaptomus mexicanus (Marsh). Journal of Marine Systems, 15: 381-390. DOI: 10.1016/S0924-7963(97)00069-9

HERBST, H. V. 1962. Crustacea aus dem Amazonasgebiet, gesammelt von professor Dr. H Sioli und Dr. R. Braun. 1. Litorale und substratgebundene cyclopoida gnathostoma (Copepoda). Crustaceana, 3 (4): 259-278. DOI: $10.1163 / 156854062 X 00508$

HERRICK, C. L. 1884. A final report on the Crustacea of Minnesota included in the orders Cladocera and Copepoda. 12th Annual Report of the Geological and Natural History. Survey of Minnesota, 5: 191.

ISHIDA, T. 1997. Eucyclops roseus, a new Eurasian copepod, and the E. serrulatus-speratus problem in Japan. Japanese Journal of Limnology, 58: 349-358. DOI: 10.3739/rikusui.58.349 ISHIDA, T. 2000. Eucyclops pacificus and E. ohtakai, two new cyclopoid copepods (Crustacea) from Japan. Biogeography, 2: 21-28.

KIEFER, F. 1936. Mitteilungen von den Forschungsreisen Prof. Rahms. Mitteilung VIII. Cyclopiden. Zoologischer Anzeiger, 115: 243-249.

KIEFER, F. 1957. Freilebende Ruderfu $\beta$ krebse (Crustacea Copepoda) des Titicacasees. Veröffentlichungen der Zoologischen Staatssammlung München, 4: 125-150.

LINDBERG, K. 1954. Cyclopides/Crustacés Copépodes) de l'Amerique du Sud. Arkiv für Zoologi, 71 (11): 193-222.

MERCADO-SALAS, N. F. 2009. Diversidad y Distribución de los Cyclopoida (Copepoda) de las zonas Áridas del Centro-Norte de México. M.Sc. Thesis. El Colegio de la Frontera Sur, Chetumal, Quintana Roo.

MERCADO-SALAS, N.F., C. POZO, J.J. MORRONE \& E. SUÁREZ-MORALES. 2012. Distribution patterns of the American species of the freshwater copepods genus Eucyclops (Copepoda: Cyclopoida). J. Crust. Biol., 32: 457-464. DOI:10.1163/193724012X626502

MERCADO-SALAS, N. \& E. SUÁREZ-MORALES. 2014a. On Kiefer's American Eucyclops (Copepoda: Eucyclopinae): $E$. delachauxi, E. prionophorus, E. bondi and E. 
leptacanthus, redescriptions and comments on historical records. Zookeys, 402: 1-41. DOI: 10.3897/zookeys.402.6112

MERCADO-SALAS, N. \& E. SUÁREZ-MORALES. 2014b. Morphological variation of Eucyclops elegans (Herrick, 1884) (Copepoda, Cyclopoida) in the Americas and comments on records of $E$. conrowae (Reid, 1992). Journal of Natural History, 48: 2007-2026. DOI: 10.1080/00222933.2014.897766

MERCADO SALAS, N.F., E. SUÁREZ-MORALES \& M. SILVA-BRIANO. 2016. Taxonomic revision of the Mexican Eucyclops (Copepoda: Cyclopoida) with comments on the biogeography of the genus. J. Nat. Hist., 50 (1-2): 25-147. DOI: 10.1080/00222933.2015. 1061715

MIRACLE, M. R., V. ALEKSEEV, V. MONCHENKO, V. SENTANDREU \& E. VICENTE. 2013. Molecular-genetic-based contribution to the taxonomy of the Acanthocyclops robustus group. Journal of Natural History, 47 (5-12): 863-888. DOI: 10.1080/ 00222933.2012 .744432

PESTA, O. 1927. Ein Beitrag zur Kenntnis der Copepodenfauna von Argentinien. Zoologischer Anzeiger, 73: 67-80.

REID. J. W. 1985. Chave de identificação e lista de referências bibliográficas para as espécies continentais Sulamericanas de vida livre da Ordem Cyclopoida (Crustacea, Copepoda). Boletim de Zoología, Universidade de São Paulo, 9: 17-143.

REID, J. W. 1990. Continental and coastal free-living Copepoda (Crustacea) of Mexico, Central America and the Caribbean Region. In: D. Navarro-López \& J.G. Robinson (eds.): 175-213. Diversidad Biológica en la Reserva de la Biosfera de Sian Ka'an, Quintana Roo, México. Centro de Investigaciones de Quin- tana Roo (CIQRO) and Program of Studies in tropical Conservation (PSTC, Univ. of Florida). Chetumal, Quintana Roo, Mexico.

REID, J. W. 1991. The Stillman Wright collection of Copepoda (Crustacea) from South America in the National Museum of natural History, Smithsonian Institution. Proceedings of the Biological Society of Washington, 104 (4): 736-741.

REID, J.W. 1992. Copepoda (Crustacea) from fresh waters of the Florida Everglades, U.S.A., with a description of Eucyclops conrowae n. sp. Transactions of the American Microscopical Society, 111: 229-254.

ROCHA, C. E. F. 1998. New morphological characters useful for the taxonomy of the genus Microcyclops (Copepoda, Cyclopoida). Journal of Marine Systems, 15: 425-431.

ROCHA, C. E. F, \& M. J. C. BOTELHO. 1998. Maxillopoda-Copepoda. Cyclopoida. In: Catalogue of Crustacea of Brazil. P.S. Young (ed.): (Série Livros no. 6) 129-166. Museu Nacional, Rio de Janeiro, Brazil.

SANTOS, L \& C. F. S. ANDRADE. 1997. Survey of cyclopoids (Crustacea, Copepoda) in Brazil and preliminary screening of their potential as dengue vector predators. Revista de Saúde Pública, 31 (3): 221-226.

SILVA, W. M. 2008. Diversity and distribution of the free-living freshwater Cyclopoida (Copepoda: Crustacea) in the Neotropics. Brazilian Journal of Biology, 68 (4): 1099-1106. DOI: 10.1590/S1519-69842008000500016

SMITH, K. E. \& C. H. FERNANDO. 1980. Guía para los copépodos (Calanoida y Cyclopoida) de Cuba. K.E. Smith (ed.): 28. Academia de Ciencias de Cuba. La Habana, Cuba.

SCHMINKE, H. 1976. The ubiquitous telson and the deceptive furca. Crustaceana, 30 (3): 292-300. 